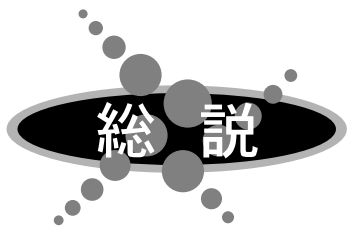

\section{放射線抵扰性細菌の新規DNA修復促進タンパク質}

\author{
日本原子力研究開発機構量子ビーム応用研究部門
}

量子ビーム遺伝子資源研究グループ 佐藤勝也，大庭寛史，鳴海一成

\begin{abstract}
The radioresistant bacterium Deinococcus radiodurans possesses the efficient repair capacity to DNA double strand breaks. By analyzing the DNA damage repair-deficient mutant, a novel DNA repair promoting protein PprA that plays a critical role in the radiation resistance was identified. Here we review our current understanding of DNA repair and radiation response mechanisms around PprA protein.
\end{abstract}

Deinococcus radiodurans / DNA repair / PprA / PprI / radiation response / RecA

\section{1. はじめに}

遺伝情報の担い手であるDNAを安定に保持し後代に 伝えていくことは, 生物が種を存続させていく上で必 須であるが, 生物は常にDNAに損傷※を被る環境に曝 されている.どんな生物でも, DNA 損傷を修復する能 力をもっており, その修復能力を超えてDNAに損傷を 受けたときに初めて障害となる。したがって，生命維 持はDNA損傷をどれだけ効率良く正確に修復するかに かかっており, 生命維持の根幹機能である DNA 修復※ 能力を詳細に明らかにすることは, 巧妙な生命現象を 理解する上で非常に大切である. 放射線はDNAに重篤 な損傷を引き起こす原因の 1 つであるが, 生物種全体 では，放射線に対する感受性に非常に大きな違いがあ る (Fig. 1)。これはおもに, DNA修復能力の差による ものである.よって, 放射線高感受性の生物を解析し ても, 生物のもつDNA修復能力の限界と可能性を明ら かにすることは困難であり, 非常に高いDNA修復能力 をもつ生物のDNA修復機構を解明することが重要とな る.

放射線抵抗性細菌※の代表菌種であるDeinococcus radiodurans は, 1956年に単離された最初の極限環境微 生物である (Fig. 1) ${ }^{1)}$. この細菌は, 他の生物にとって 致死的効果あるいは変異原性を示す電離放射線, 紫外 線, 薬剤に対してきわめて抵抗性であり，これはこの 菌が非常に高いDNA修復能力をもつことに起因してい る. 特筆すべきは, D. radiodurans が DNA 損傷の中で も最も致死的効果の高いDNA2 本鎖切断損傷に対して も, 高い修復能力をもっている点である ${ }^{2)}$. この菌は,
ゲノム中に 100 を超えるDNA2 本鎖切断が生じてもそ れを修復できる. 近年, DNA 修復機構解明のための分 子生物学的研究が急速に進展しており, 1999年には米 国ゲノム研究所によって, D. radioduransの全ゲノムシー ケンスが公開された ${ }^{3)}$. しかしながら, 半数を超える遺 伝子が機能未知であり, ゲノム解析だけではこの菌の もつ効率的なDNA修復能力を明らかにすることはでき なかった. 現在, D. radioduransのDNA修復機構の解 明研究は, ポストゲノム時代に突入し, DNA 修復タン パク質の機能解析に重点が移行したといえる.

われわれの研究グループでは, D. radioduransの放射 線感受性变異株の解析から, この菌の放射線抵抗性に 重要な役割を担う新規 DNA 修復促進タンパク質 PprA を同定し, その機能解析と共に放射線応答機構につい ても研究を進めてきた. 本総説では, 新規DNA 修復夕 ンパク質PprAを中心としたD. radioduransのDNA修復 機構と放射線応答機構についての最近の知見を紹介す る.

\section{2. 新規DNA修復タンパク質PprAの同定}

D. radioduransの放射線感受性変異株である KH311株 (Fig. 2) ${ }^{4)}$ の放射線感受性の原因遺伝子を同定するため に, 野生株ゲノムDNAを用いた形質転換による放射線 抵抗性の回復を指標とした相補試験を行ったところ, 既 知の遺伝子とは全く相同性を示さない遺伝子が関係し ていることがわかった. KH311株では, その遺伝子中 の446番目の塩基 $\mathrm{G}$ が Aに 1 塩基変異 (pprA446) を起 こしており, この変異によって遺伝子産物の 149 番目 のアミノ酸のグリシンがグルタミン酸に変化してい

\title{
A Novel DNA Repair Promoting Protein from the Radioresistant Bacterium
} Katsuya SATOH, Hirofumi OHBA and Issay NARUMI Gene Resource Research Group, Quantum Beam Science Directorate, Japan Atomic Energy Agency 


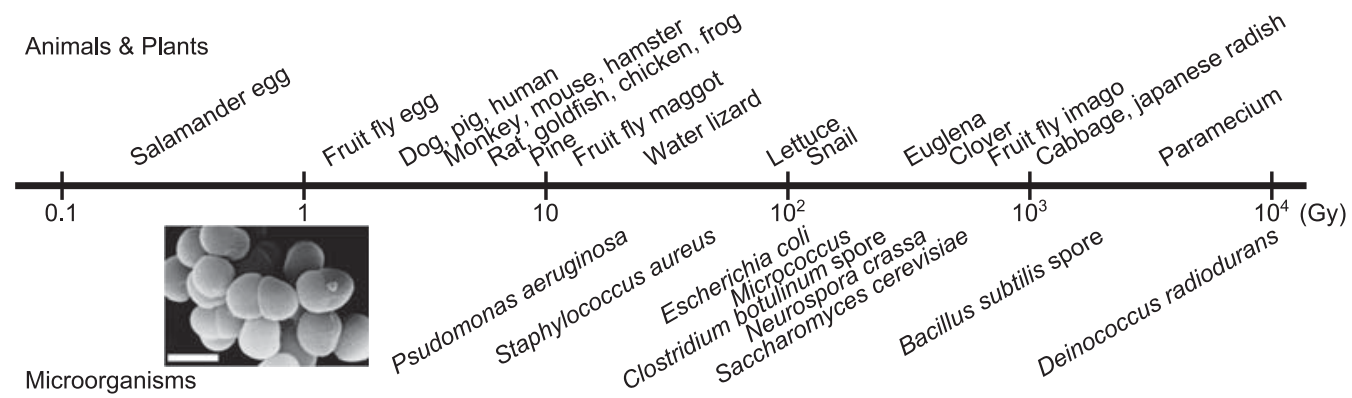

Fig. 1 Radioresistance in living organisms. The radioresistance represents the 50\% lethal dose of acute irradiation. Scanning electron micrograph shows Deinococcus radiodurans. Bar indicates $1 \mu \mathrm{m}$.

ることがわかった．同定した遺伝子の野生型をKH311 株に導入することで, $\gamma$ 線, 紫外線, 抢よびマイトマイ シン C に対する感受性が D. radiodurans の野生株と同 程度にまで回復したことから，この遺伝子をpprA (pleiotropic protein promoting DNA repair ; DNA 修復を 促進する多面的タンパク質) 遺伝子と命名した ${ }^{5)}$. さら に, D. radiodurans ゲノム中の pprA 遺伝子に薬剤耐性 遺伝子を直接插入する変異導入法によって作製した $p p r A$ 遺伝子破壞株 XN1 は, $\gamma$ 線に対して KH311株と同 程度に高感受性を示した (Fig. 2).このことは, KH311 株のpprA446 変異はたった 1 力所の点突然変異によっ て, そのDNA 修復にかかわる機能を完全に欠失してい ることを示している.

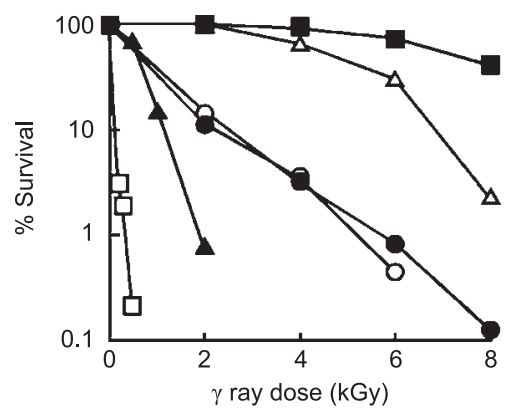

Fig. 2 Sensitivity of $D$. radiodurans to $\gamma$ rays. The percentage survival for each strain over the indicated range of doses was determined, and the mean from three independent experiments was plotted. Symbols: closed squares, strain KD8301 (wild-type); open circles, strain $\mathrm{KH} 311$ (pprA446); closed circles, strain XN1 (pprA428::cat); open triangles, strain KI696 (recA424); closed triangles, strain KS2 (recA424, pprA428::cat); open squares, strain KH840 (pprl307::IS8301).

\section{3. 新規DNA修復タンパク質PprAの機能解析}

RecAタンパク質抢よびその機能ホモログは, 大腸菌 からヒトに至るまですべての生物に保存されており, DNA組換え修復機構に重要な役割を果たしている ${ }^{6}$. $D$. radioduransに扑いても, RecAタンパク質の機能欠損変 異株は, $\gamma$ 線に対して非常に感受性である7)-9). そこで, DNA修復機構におけるPprAおよびRecAタンパク質の 相互作用を解析するため, DNA 組換え活性の欠失した 変異型 recA424 遺伝子 9 ) もつ変異株 KI696 の pprA 遺 伝子を破壊した recA pprA 遺伝子二重変異株 KS2 を作 製した。 recA p prA 遺伝子二重変異株は, $\gamma$ 線に対して pprA遺伝子破壞株よりも高い感受性を示した (Fig. 2). このことから, PprA タンパク質は, RecA タンパク質 のDNA 組換え活性に依存しないDNA 修復機構に関与 していると考元られた.では, PprAタンパク質はDNA 修復機構において，一体どのような役割を担っている

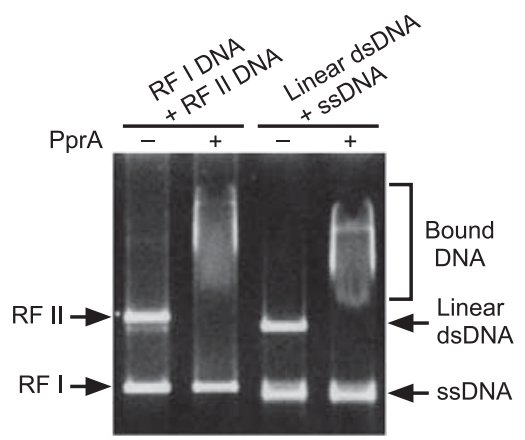

Fig. 3 DNA binding property of PprA. Purified PprA was incubated with $\phi$ X174 DNA (RF I; supercoiled form, RF II; relaxed form carrying single strand break, ApaLI-linearized dsDNA carrying double strand break, and circular ssDNA), and subjected to agarose gel electrophoresis. 
(a)

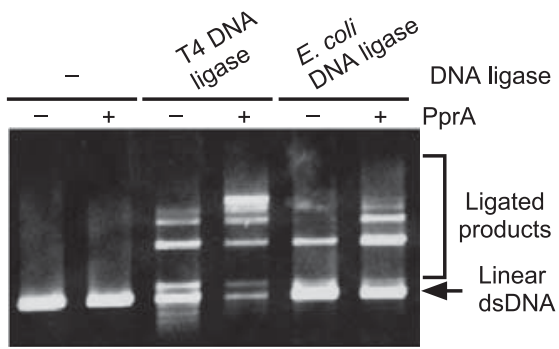

(b)

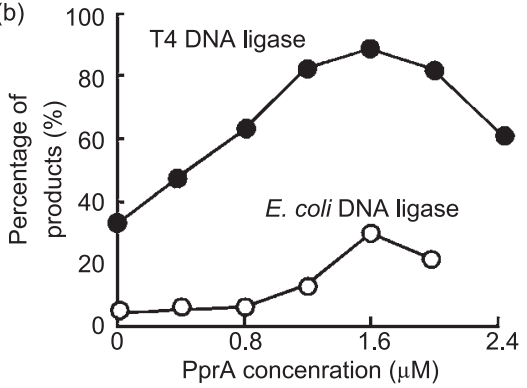

Fig. 4 Stimulation of DNA ligation activity by PprA. (a) ApaLI-linearized $\phi \mathrm{X} 174 \mathrm{dsDNA}$ was incubated with T4 DNA ligase or $E$. coli DNA ligase in the absence or presence of purified PprA, and subjected to agarose gel electrophoresis. (b) The percentage of ligated product over a range of PprA concentration was determined, and the mean from three independent experiments was plotted.

\section{のだろうか.}

これに取り組むべく,われわれは, PprAタンパク質 を精製し, 生化学的機能解析を試みた. pprA 遺伝子を 発現させた大腸菌から精製したPprAタンパク質は, 分 子量約 $31 \mathrm{k}$ で，2価の陽イオンの存在下で 2 本鎖DNA と結合する活性を示した. DNA 結合能は, DNA 鎖切断 をもたないDNAよりも, DNA1 本鎖およびDNA2 本鎖 切断をもつ2本鎖DNAに対して非常に強いという特徵 をもっていた (Fig. 3 $)^{10)}$. PprA タンパク質と直鎖状 2 本鎖DNAとの複合体は, 大腸菌エキソヌクレアーゼIII のDNA 分解活性を阻害するが, ATPおよびNAD依存 性のDNA リガーゼのDNA 末端再結合活性を促進する ことがわかった（Fig. 4)。このような, PprAタンパク 質の性質は，真核生物の非相同末端結合修復にかかわ る $\mathrm{Ku}$ タンパク質の性質 ${ }^{11)}$ に類似していることから, PprA タンパク質は, D. radioduransの非相同末端結合修 復機構に非常に重要な役割を担っていると考えられ $3^{5)}$.

\section{4. 新規DNA修復タンパク質PprAの発現制御解 析}

D. radioduransの優れたDNA 2 本鎖切断修復には,

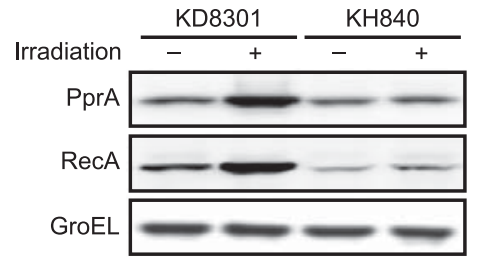

Fig. 5 Changes in intracellular PprA and RecA levels following irradiation. Cells were irradiated $(+)$ or mock irradiation (-) with $\gamma$ rays at a dose of $2 \mathrm{kGy}$, incubated in fresh medium at $30^{\circ} \mathrm{C}$ for $2 \mathrm{~h}$, and subsequently analysis by Western blot using anti-PprA and anti-RecA antisera. The level of GroEL was constant irrespective of irradiation in all the strains tested. KD8301, wildtype; KH840, pprl307::IS8301.

DNA損傷が生じた際にその修復にかかわるタンパク質 の合成が必要である ${ }^{12)}$. 近年, D. radioduransのトラン スクリプトームおよびプロテオーム解析から, DNA 修 復, 複製などに関連するさまざまな放射線誘導性の遺 伝子およびタンパク質の発現プロファイルが示されて いる ${ }^{13)}{ }^{14)}$. そこで, PprAタンパク質に対する抗体を用 いて, DNA 損傷による細胞内の PprA タンパク質の挙 動変化を調べたところ, $\gamma$ 線照射によって細胞内のPprA タンパク質の産生量の増加が観察された (Fig. 5) ${ }^{5)}$.す なわち, PprAタンパク質はRecA タンパク質と同様に 放射線誘導性タンパク質であった．しかしながら， D. radioduransの優れたDNA修復機構解明において, 放射 線応答の分子機構を明らかにすることが重要であるに もかかわらず, 放射線誘導性タンパク質をコードする 遺伝子の放射線応答プロモーターについてほとんど明 らかにされていなかった。

そこで, PprAタンパク質の放射線応答機構を明らか にするために, pprA 遺伝子プロモーターについて解析 を行った. まず, プライマーエクステンション法によ り $p p r A$ 遺伝子の異なる 3 力所の転写開始点 $(-156,-154$ および-22）を同定した（Fig. 6a）。 $\gamma$ 線照射後の培養 によって, 3 力所の転写開始点での転写産物量の増加が 見られたことから, pprA遺伝子発現には, 遠位 (-156 および-154 を含む領域) および近位（-22 を含む領域） の 2 つの放射線応答プロモーターが関与していること を明らかにした ${ }^{15)}$. 次に, 放射線応答に関与するプロ モーター領域を同定するため, ルシフェラーゼ遺伝子 を用いたレポーターアッセイにより， $\gamma$ 線照射による $\operatorname{pprA}$ 遺伝子プロモーター活性変動を解析した. その結 果, 遠位のプロモーターは-208 から-156 領域に, 近 位のプロモーターは-57から-22領域に存在すること, そして, -57 から-38 領域が最小プロモーター領域であ ることを明らかにした (Fig. 6b ${ }^{15)}$. 
(a)

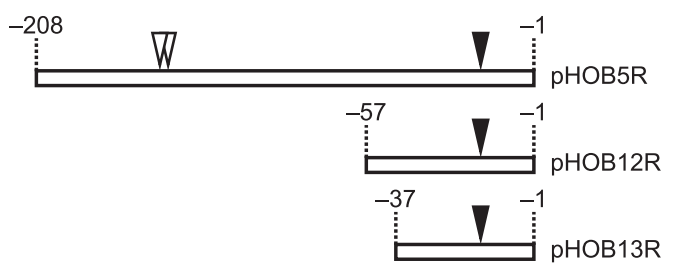

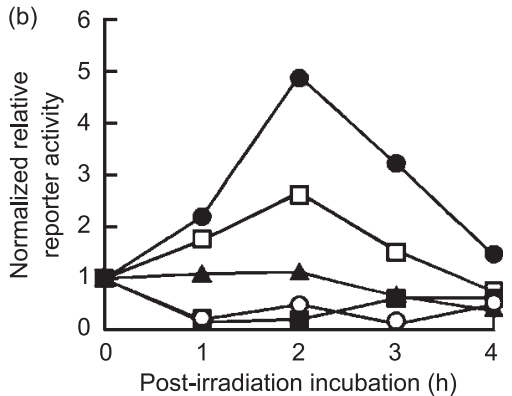

Fig. 6 Functional analysis of the radiation responsive promoter of the pprA. (a) The upstream region of the pprA cloned in the luciferase reporter vector. Numbers indicate relative position with respect to translation initiation site. Open and closed triangles represent distal (-156 and -154) and proximal (-22) transcriptional start site, respectively, determined by primer extension analysis. (b) Changes in the pprA promoter activity of $D$. radiodurans strains carrying reporter plasmid following irradiation. Cells were irradiated with $\gamma$ rays at a dose of $2 \mathrm{kGy}$. Values are relative reporter activity normalized to that of 0 time point for each dose as 1 . Symbols: closed circles, strain $R_{1}$ (wild-type) carrying pHOB5R; open squares, strain $R_{1}$ carrying pHOB12R; closed triangles, strain $\mathrm{R}_{1}$ carrying pHOB13R; open circles, strain JAK1 (pprl536::aph) carrying pHOB5R; closed squares, strain JAK1 carrying pHOB12R.

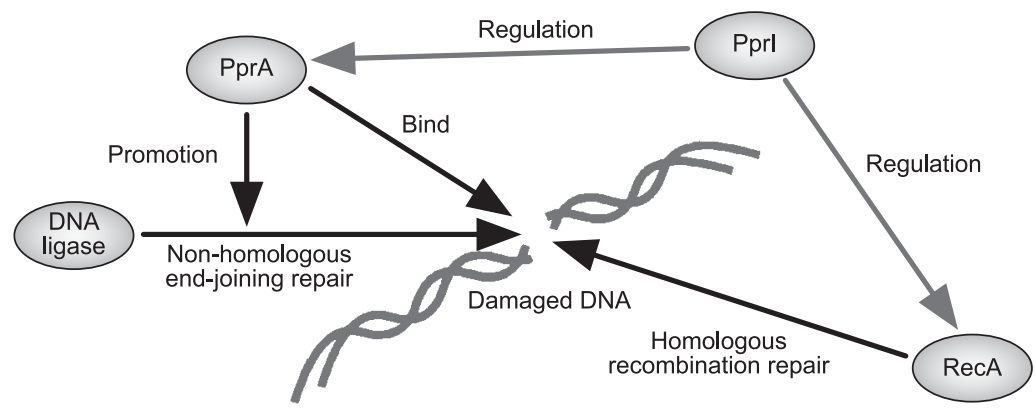

Fig. 7 Hypothesis of double strand breaks repair mechanism of $D$. radiodurans. Following DNA damage, Pprl up-regulates the expressions of the pprA and recA. PprA and RecA play crucial roles in non-homologous end-joining and homologous recombination repairs, respectively.

またこれまでにD. radioduransから，別の放射線高 度感受性変異株 KH840（Fig. 2）が分離されている ${ }^{16}$. KH840 株において, DNA 損傷による細胞内のPprA お よびRecAタンパク質の挙動変化を調べたところ, DNA 損傷後に p prA 遺伝子および recA 遺伝子の発現誘導が 起こっていないことが明らかになった（Fig. 5)。 そこ で, KH840株の放射線感受性の原因遺伝子を同定した ところ, 既知の遺伝子とは全く相同性を示さない遺伝 子内に挿入配列 IS $8301^{177}$ が転移していた。 この新規遺 伝子は $p p r A$ 遺伝子および $r e c A$ 遺伝子の発現誘導に関 与することから, この遺伝子を $p p r I$ (inducer of pleiotropic protein for DNA repair; 多面的タンパク質の誘導制御因 子）遺伝子と命名した ${ }^{18)}$. さらに, pprI遺伝子破壊株 JAK1では, 野生株とは異なり pprA遺伝子プロモーター の活性が見られなかったことから (Fig. 6b), pprA遺伝 子発現はpprI遺伝子産物によってプロモーターレベル で制御されていることを明らかにした ${ }^{15)}$.
これまでに得られた知見を基に, D. radioduransにお ける DNA2 本鎖切断修復機構を Fig. 7 に示す. このよ うに, D. radioduransは, RecAタンパク質が中心的な 役割を担う既知のDNA 修復機構を備えつつ, 新規転写 制御因子 PprI に制御される独特な DNA 修復機構を兼 亦備えることで卓越したDNA修復能力を有していると 考えられる。

\section{5. おわりに}

今後は, どのようにDNA1 本鎖およびDNA2 本鎖切 断をもつ 2 本鎖 DNA と作用しているかなど PprA タン パク質の機能を分子レベルで詳細に解明していくため に, PprAタンパク質の結晶構造解析によって立体構造 を明らかにする必要がある. 現在, タンパク質の結晶 化条件の最適化を進めているところである ${ }^{19}$.さらに, PprA タンパク質の DNA 結合活性に必要な領域を明ら かするために, ランダム変異導入によるPprA タンパク 
質の機能欠損変異体の作製を試みている.

PprA タンパク質は, 遺伝子工学分野における試験管 内ライゲーション促進試薬として, 最近, 商品化され ている ${ }^{20)}$. また, PprAタンパク質は, 放射線被曝を受 けた哺乳動物細胞中のDNA損傷を可視化する技術の開 発にも利用されている21).さらに, pprA遺伝子プロモー ター活性測定用ルシフェラーゼレポータープラスミド を用いたアッセイ系は, 受けた放射線量に依存したル シフェラーゼ活性の定量性 ${ }^{15)}$ を活かして, 生物線量計 としての利用が可能であろう。 D. radiodurans の DNA 修復機構に関連するタンパク質は, 優れたDNA修復機 構の解明研究に重要なだけではなく, 放射線リスク評 価あるいはDNA鎖切断を引き起こす物質を検索するた めの遺伝毒性試験に新しい解析ツールを提供すること にも貢献できるなどさまざまな分野において応用可能 である。このように，D. radiodurans は有用な遺伝子資 源として今後の応用がますます期待される.

\section{謝 辞}

最後に，放射線抵抗性細菌の研究について，有益な 御助言賜りました渡辺宏博士（ラジエ工業），北山滋 博士（当時，原子力機構遺伝子資源），小林泰彦博士 (原子力機構マイクロビーム), 舟山知夫博士 (同), 菊 地正博研究員（同），並びに柳沢忠博士（宇都宮大農 学部）に厚く感謝し上げます。なお，本総説に示し た研究成果の一部は, 原子力基盤クロスオーバー研究 による助成を受けています。

\section{文 献}

1) Anderson, A. W. et al. (1956) Food Technol. 10, 575-578.

2) Narumi, I. (2003) Trends. Microbiol. 11, 422-425.

3) White, O. et al. (1999) Science 286, 1571-1577.

4) Kitayama, S. et al. (1983) J. Bacterial. 155, 1200-1207.

5) Narumi, I. et al. (2004) Mol. Microbiol. 54, 278-285.

6) Brendel, V. et al. (1997) J. Mol. Evol. 44, 528-541.

7) Moseley, B. E. B. and Copland, H. J. (1975) J. Bacterial. 121, 422-428.

8) Narumi, I. et al. (1999) Mutat. Res. 455, 189-199.

9) Satoh, K. et al. (2002) J. Biochem. 131, 121-129.

10) Murakami, M. et al. (2006) Biochim. Biophys. Acta. 1764, 20-23

11) Kysela, B. et al. (2003) J. Biol. Chem. 278, 22466-22474.

12) Kitayama, S. and Matsuyama, A. (1971) Agric. Biol. Chem. 35, 644-652.

13) Liu, Y. et al. (2003) Proc. Natl. Acad. Sci. USA 100, 41914196.

14) Tanaka, A. et al. (1996) Radiat. Environ. Biophys. 35, $95-$ 99.

15) Ohba, H. et al. (2005) Gene 363, 133-141.

16) Kitayama, S. and Matsuyama, A. (1975) Mutat. Res. 29, 327-332.

17) Islam, S. M. et al. (2003) Genes Genet. Syst. 78, 319-327.

18) Hua, Y. et al. (2003) Biochem. Biophys. Res. Commun. 306, 354-360.

19）安達基泰ら：第 5 回蛋白質科学会（2005年6月 30 日 - 7 月2日)。

20) http://nippongene.com/pages/products/clomod/mod_e/tablunt_lig/index.html

21) Satoh, K. et al. (2006) Mutat. Res. 596, 36-42. 


\section{放射線抵抗性細菌の新規DNA修復促進タンパク質}

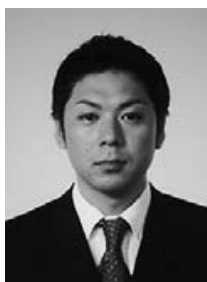

佐藤勝也
佐藤勝也（さとう かつや）

日本原子力研究開発機構量子ビーム応用研究部門量子ビーム遺伝子資源研究グループ研究員

研究内容: 放射線抵抗性細菌のDNA 修復機構の解明研究

URL: http://www.taka.jaea.go.jp/rab_div/index_j.html

連絡先： $\mathbf{7} 370-1292$ 群馬県高崎市綿貫町 1233

E-mail: sato.katsuya@jaea.go.jp

大庭寛史（おおば ひろふみ）

日本原子力研究開発機構量子ビーム応用研究部門量子ビーム遺伝子資源研究グループ博士研究員

連絡先：干370-1292 群馬県高崎市綿貫町 1233

E-mail: ohba.hirofumi@jaea.go.jp

鳴海一成（なるみ いっせい）

日本原子力研究開発機構量子ビーム応用研究部門量子ビーム遺伝子資源研究グループグループリーダー 連絡先：干370-1292 群馬県高崎市綿貫町 1233

E-mail: narumi.issei@jaea.go.jp 